\title{
Mass cannibalism in the Linear Pottery Culture at Herxheim (Palatinate, Germany)
}

\author{
Bruno Boulestin ${ }^{1}$, Andrea Zeeb-Lanz ${ }^{2}$, Christian Jeunesse ${ }^{3}$, \\ Fabian Haack ${ }^{2}$, Rose-Marie Arbogast ${ }^{3} \&$ Anthony Denaire ${ }^{3,4}$
}

The Early Neolithic central place at Herxheim is defined by a perimeter of elongated pits containing fragments of human bone, together with pottery imported from areas several hundred kilometres distant. This article offers a context for the centre, advancing strong evidence that the site was dedicated to ritual activities in which cannibalism played an important part.

Keywords: Europe, Germany, Linearbandkeramik pottery, LBK, human bone, cannibalism, butchering

\section{Introduction}

Since the early 1990s, archaeological and anthropological research into violence and war has become increasingly dynamic. The number of recent publications on the subject confirms this growing interest, for instance in the theoretical basis for the understanding of violence and war, and their relationships with social structures (Haas 1990; Reyna \& Downs 1994; Keeley 1996; Martin \& Frayer 1997; Carman \& Harding 1999; Kelly 2000; Guilaine \& Zammit 2001; Leblanc \& Register 2003; Arkush \& Allen 2006).

The Neolithic of the Old World plays a particularly important part in this debate. While the problem of Neolithic violence was already tackled in early archaeological papers, it has recently been re-activated (Keeley 1996; Carman \& Harding 1999; Guilaine \& Zammit 2001; Beyneix 2001, 2007; Thorpe 2003; Christensen 2004; Pearson \& Thorpe 2005; Schulting \& Fibiger 2008), and debates about the importance of violence during the Neolithic, and how it should be qualified (should we speak of war?) remain heated. In particular, several discoveries made in Germany and Austria in the past 30 years raise the question of the reality of a climate of collective violence as early as the beginning of the Neolithic, that is at the end of the Linear Pottery Culture (end of the sixth millennium cal $\mathrm{BC})$. Due to the exceptional nature of the cases, all from a limited chronological period,

1 UMR 5199-PACEA, Laboratoire d'anthropologie des populations du passé, Université Bordeaux 1, Avenue des Facultés, 33405 Talence Cedex, France

2 Generaldirektion Kulturelles Erbe Rheinland-Pfalz, Direktion Landesarchäologie, Außenstelle Speyer, Kleine Pfaffengasse 10, 67346 Speyer, Germany

3 UMR 7044, Université Marc Bloch Strasbourg 2, Rue René Descartes, 67084 Strasbourg, France

4 Antea-Archéolegie, 11 rue de Zurich, 68440 Habsheim, France

Received: 18 March 2009; Accepted: 5 May 2009; Revised: 27 May 2009

ANTIQUITY 83 (2009): 968-982 
even if they are still few in number, some researchers have evoked a malfunctioning and/or a generally warlike climate among these first agricultural communities (Farrugia 2002; Wild et al. 2004), whereas others have rejected this suggestion (Orschiedt \& Haidle 2007, 2008; Zeeb-Lanz 2009). The discoveries usually mentioned in this context are the mass grave at Talheim (Wahl \& König 1987; Wahl \& Strien 2007), some of the human remains from the ditched site at Vaihingen (Krause 1998), both in Baden-Württemberg, those from the ditches in the settlement at Asparn-Schletz, Lower Austria (Teschler-Nicola et al. 1997; Windl 1998), and Herxheim (Palatinate). The latter is of particular relevance: although regularly quoted, above all because of the striking presence of hundreds of human skullcaps found in the ditches, the human remains have never been studied in detail. They have been tackled in the main publications only from a general point of view, with no precise quantitative analyses or exhaustive studies of bone modifications (Orschiedt \& Haidle 2007; Zeeb-Lanz et al. 2007). Lacking this detailed study, these publications (including the most recent ones: Orschiedt \& Haidle 2008; Zeeb-Lanz \& Haack 2008) conclude in favour of specific funerary practices in several stages, and against the theory of slaughter and war.

In 2008, one of us (B.B.) began a detailed study of the human bone assemblage found in recent excavations (2005-2008), which is here amplified into the analysis of just one deposit (deposit no. 9), in order to define clearly the processes involved in the treatment of the remains found on the site. We present in this paper the results of this analysis, which lead to conclusions far removed from those presented in earlier studies, and give rise to some new perspectives.

\section{The site of Herxheim}

The site of Herxheim is situated in the south of the German Federal State of Rhineland-Palatinate (Figure 1a), on a small spur above a loess plateau containing many prehistoric sites and at the confluence of two small rivers. It was discovered in the 1980s by surface prospection. The GDKE Rheinland-Pfalz, Direktion LandesarchäologieSpeyer (Rhineland-Palatinate State Office for the Preservation of Historical Monuments) then carried out two excavation campaigns (1996-1999 and 2005-2008). The first, directed by Annemarie Häußer, was a rescue excavation necessitated by the construction of an industrial and commercial estate. The second was conceived as a planned excavation intended to complement the earlier data and provide more detail. It was placed under the scientific responsibility of Andrea Zeeb-Lanz and directed by Fabian Haack.

The structures excavated indicate a village inhabited between 5300 and 4950 BC (from the Flomborn phase to the last phase of the Linear Pottery Culture). The main structure is a trapezoid enclosure of 5 ha measuring some $250 \times 230 \mathrm{~m}$ (Figure 1b). It seems at first sight to be composed of two parallel trapezoid ditches, but in fact these ditches never existed: they are merely the product of the overlapping of a large number of oblong pits of varying length, form and depth (the deepest extended up to $4 \mathrm{~m}$ beneath the Neolithic ground level), which were dug over several centuries according to a pre-determined layout. New pits would intersect others which were already partially filled, so that the internal area 


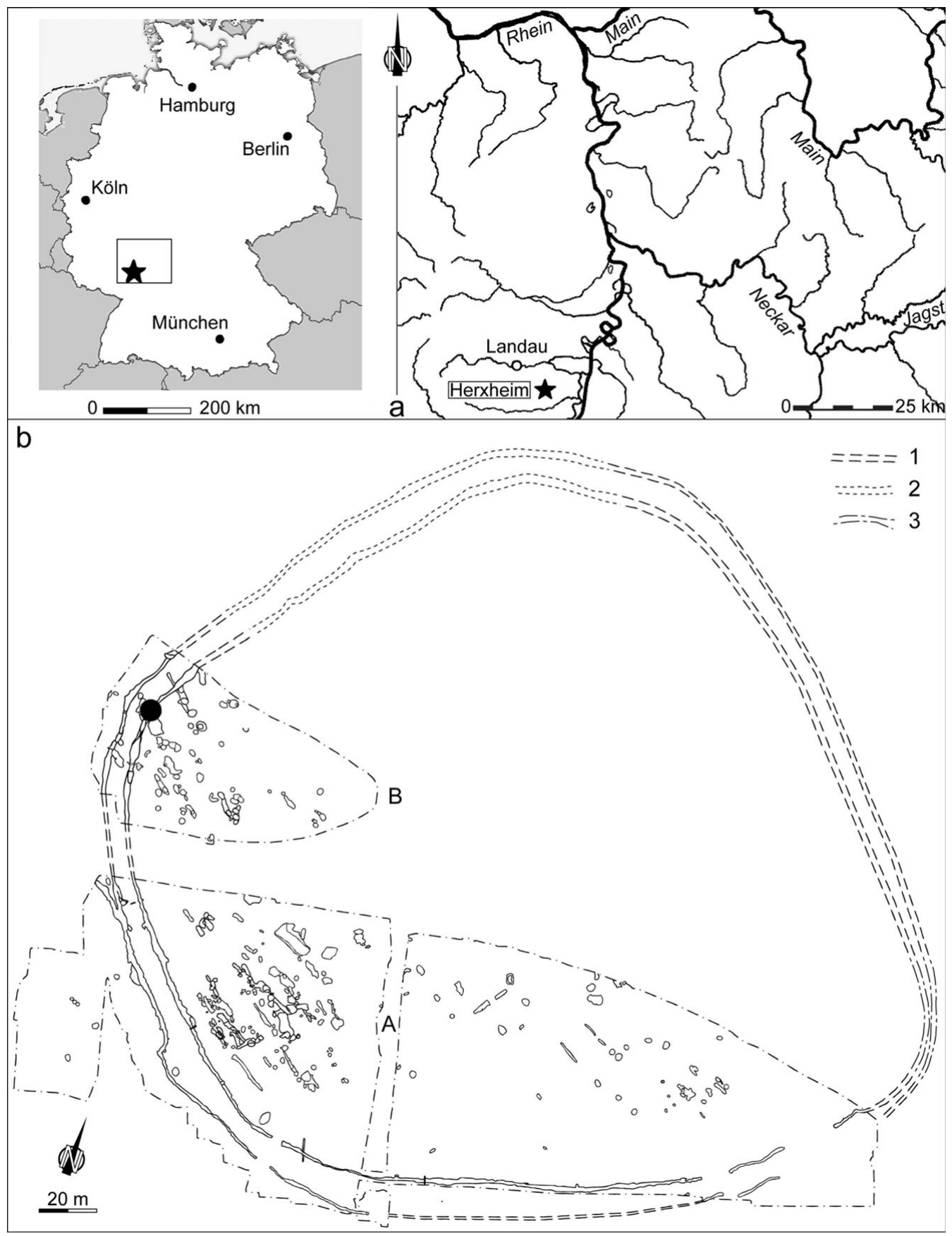

Figure 1. The Herxheim Linear Pottery Culture settlement: a) site location in Germany; b) plan of the excavation and location of deposit 9 (1. reconstruction of the ditch system; 2. ditch system as seen by geophysical prospection; 3. ditch system as revealed through test trenches; A. excavation area 1996-1998; B. excavation area 2005-2008; black circle indicates location of deposit 9 in the inner pit alignment). 
was never completely surrounded by continuous ditches. For this reason we can speak of 'pseudo-ditches' for this type of enclosure, also referred to as Rosheim type on the basis of the excavations at the eponymous Linear Pottery Culture enclosure in France (Jeunesse $\&$ Lefranc 1999). The two chains of pits forming the enclosure certainly never served as protection, but rather as a symbolic boundary for a settlement area which was probably also used for ceremonies. This kind of enclosure seems to be quite rare in the Early Neolithic. Only a few settlements had such enclosures, which indicates that they enjoyed a central position on a micro-regional or even regional level. The fact that the village of Herxheim had held such a position since the Early Linear Pottery Culture certainly explains why it was so important during the Final Linear Pottery period. Otherwise the interior of the enclosure, which has been widely destroyed by erosion, has yielded only a small number of settlement pits and a few graves (Figure 1b).

\section{Deposits in the pseudo-ditches}

The function of the enclosure seems to have changed during the Final Linear Pottery period. New oblong pits were no longer excavated, and quite a number of existing ones received spectacular deposits composed mainly of human remains, but also of fauna, ceramics, stone and bone tools in various proportions, as well as rare decorative artefacts. In only a few cases were these deposits laid in pits specially excavated for the event. Around 80 such deposits have already been discovered.

In most of them the human remains appear as a scatter of bone fragments, sometimes as many as 2000 (Figure 2). The skulls seem to have been treated specially, seldom being found intact but often as calottes (Figure 3a), sometimes intentionally grouped to form a kind of 'nest'. Other, much less numerous, deposits have yielded intact bones from partially dislocated bodies which still show some anatomical connections (torsos, limbs or parts of limbs). The human remains discovered so far belong to about 500 individuals, but since the area excavated corresponds to barely half the enclosure, we can assume that in fact more than 1000 individuals were involved.

Faunal elements found in the deposits had been carefully selected, and differ from the domestic waste in settlement structures. Bones usually come from the extremities (skull and legs). Dog bones are quite numerous, and several deposits also yielded horn-cores from bovinae.

The artefacts found with the human remains are generally also intentionally mutilated. The pottery, the most abundant category, had been systematically broken before being deposited. It is chronologically homogenous, showing that the deposition period of human remains lasted a maximum of 50 years, and possibly far less, but is stylistically varied, in quite a number of cases including elements originating up to $400-500 \mathrm{~km}$ away (Elbe Valley). All together, the area of provenance or so-called 'supply basin', extends to some $2000-3000 \mathrm{~km}^{2}$. Even if the question of the modalities of these transfers remains unsolved (pottery styles and even pottery themselves can travel long distances without long-distance movement of people), the reality of contacts with the concerned area is indisputable. Let us not forget the very high quality of this pottery: these outsider wares 

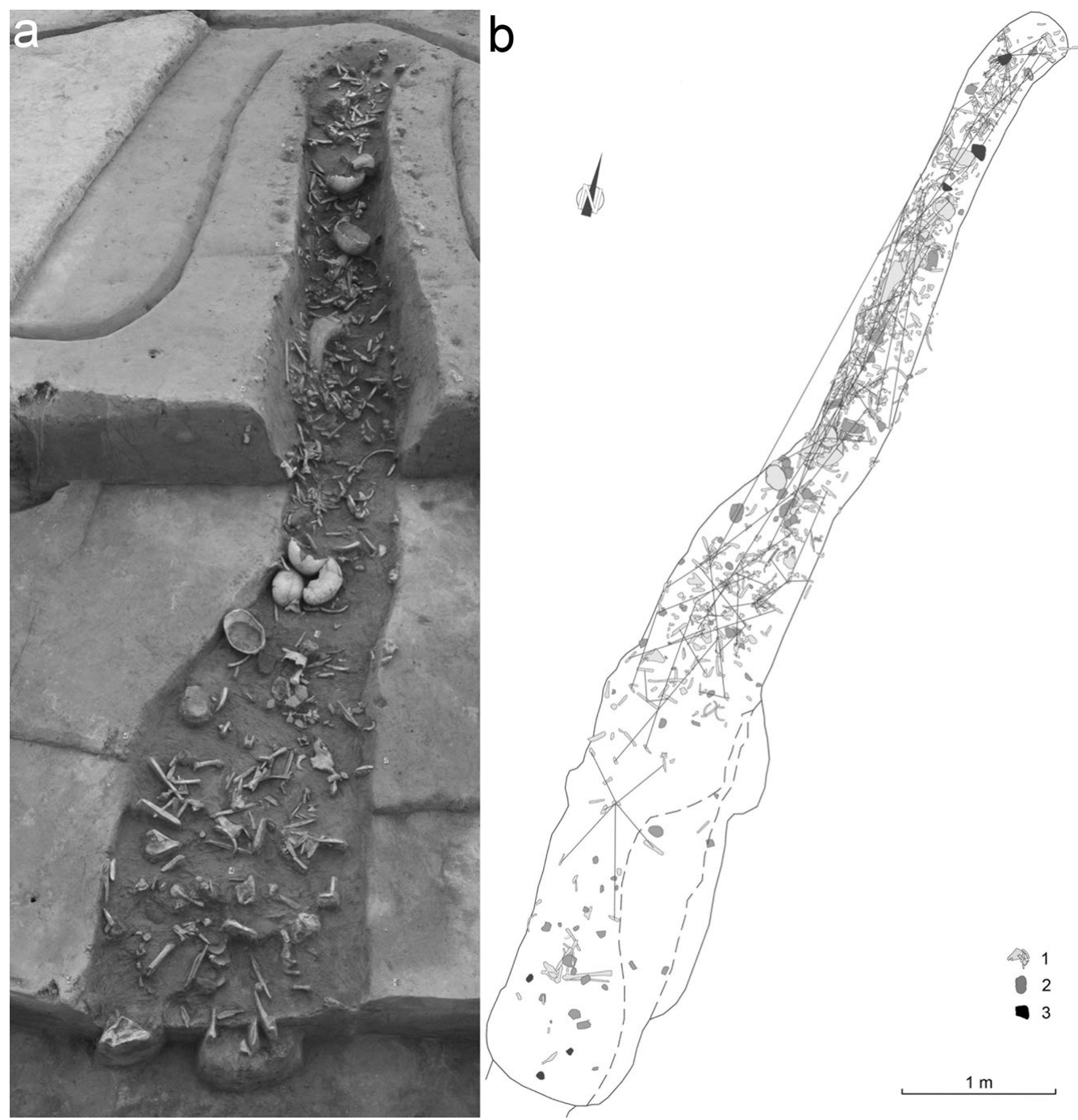

Figure 2. Deposit 9: view after excavation of the upper level of the deposit, with (right) plan of the deposit showing conjoined fragments: 1) bone; 2) pottery sherd; 3) grinding stone.

are among the most remarkable pieces of the various ceramic traditions found at the site.

\section{Human remains from deposit 9}

Deposit 9 was excavated during the summer of 2007 and is among the few deposits which were subjected to a stratigraphic excavation leaving all artefacts in place. This allowed an overview of the feature in situ (Figure 2). The deposit was located in the lower level of the fill of one of the pits in the inner pseudo-ditch, and is over $7.75 \mathrm{~m}$ long and of irregular width. The finds are extremely dense, reaching a level seldom found in other deposits, making it 


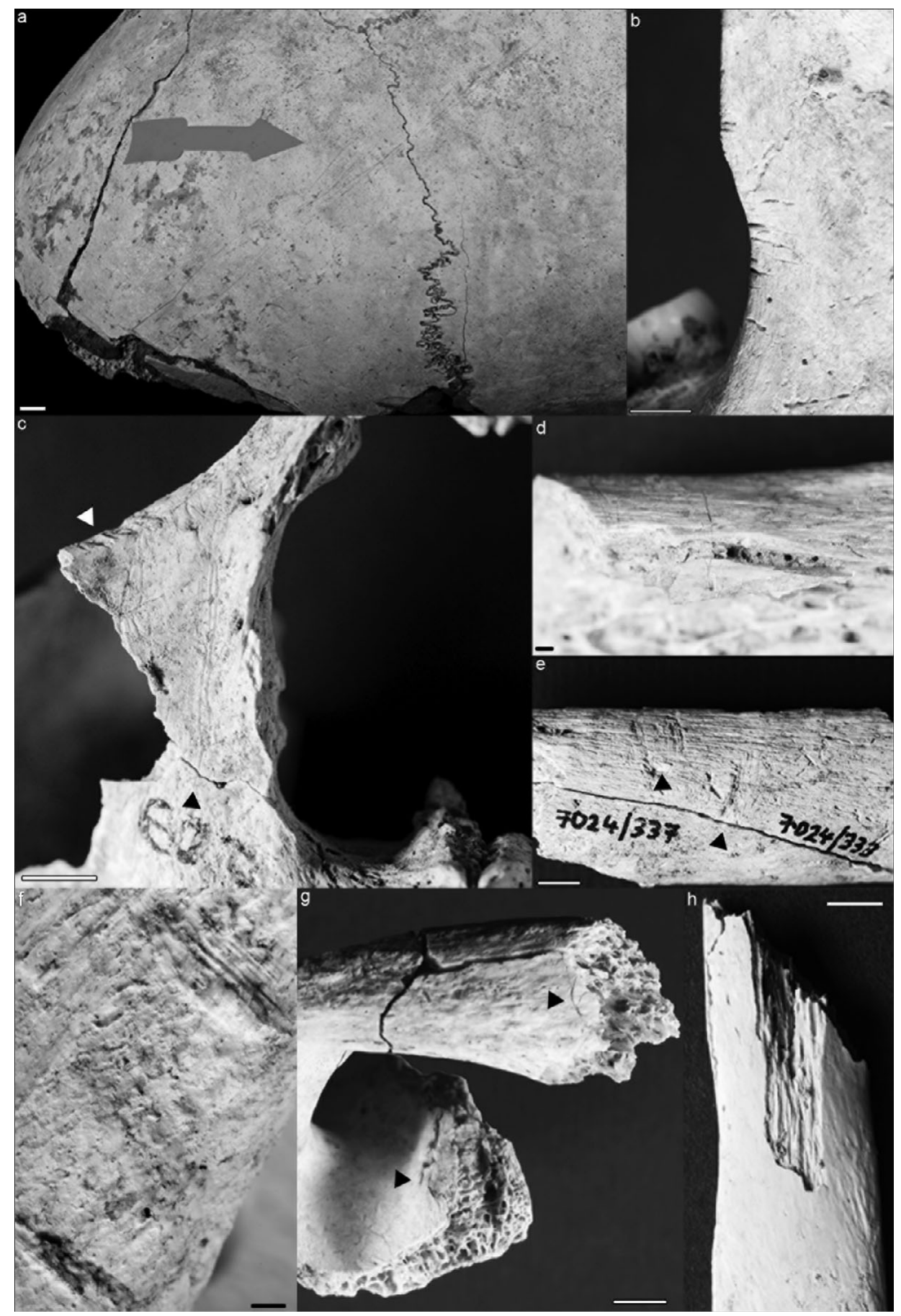

Figure 3. Examples of human bone modifications related to butchery processes: a) skinning marks on a calotte; b) cutmarks on a mandibular ramus; c) scrapemarks and cutmarks on the orbital margin, on a maxilla; d) inner conchoidal scar with adhering flake on a femur; e) anvil striae on a femur; f) percussion striae on a femur; $g$ ) crushing on a scapula; h) peeling on a rib. (White bars $=5 \mathrm{~mm}$, black bars $=1 \mathrm{~mm}$ ). 
one of the most quantitatively important of all excavated deposits, yet it is also perfectly representative of most of them (as regards the high degree of fragmentation of the bone remains). The study of the distribution of conjoining sets of human remains and ceramics shows that all the objects were deposited at the same time in a single event, and that the artefacts and bones discovered at the southern end, which were barely mutilated and still partially connected, should probably be considered separately.

The identification, classification and quantification of the bone from deposit 9 were made according to the conventional procedures for human anatomy and quantitative analysis. Each piece was systematically analysed with a binocular microscope (Leica ${ }^{\circledR}$ MZ 16) to observe bone modifications. These modifications were studied and quantified according to criteria established elsewhere (White 1992; Boulestin 1999). The study of the breakage, particularly for the larger long bones of the limbs, was carried out according to procedures specifically developed for human bone (Villa \& Mahieu 1991; White 1992; Boulestin 1999).

The human assemblage consists of 1906 very well preserved specimens with a total weight of $6468.5 \mathrm{~g}$, of which 1184 specimens could be precisely determined, that is $62.1 \%$ ( $5975.5 \mathrm{~g}$ or $92.4 \%$ of the total weight). These remains belong to at least 10 individuals: two perinates, one aged 34 to 36 weeks in utero; two infants aged respectively 5 to 7 years and about 15 years; and six adults (among them at least one man). The refitting of fragments allowed 75 conjoining sets consisting of a total of 217 specimens to be identified. Most sets are composed of only two specimens, although some can contain as many as 13 . A count of the pieces after refit produced a total minimum number of skeletal elements (MNE) of 359, without including the isolated teeth (Table 1).

The human bones show abundant and unequivocal evidence of human-induced modifications, the antiquity of which is attested by matrix superimposition (on fractures or cut marks), patina, as well as by multiple cut marks crossing ancient fracture edges of refit pieces discovered in different parts of the deposit (Figure 3). Modifications induced by the cutting up of corpses are cut marks and scrape marks. Among the former we can distinguish between two major types; on the one hand cut marks of various length and depth, isolated or with minimal concentrations, corresponding to the cutting of soft tissue (often ligaments and tendons for the purpose of disarticulation) or to skinning. On the other hand short, shallow cut marks, at right angles to the long shaft of the bones, appear in highly concentrated ladder-rung like series and correspond to defleshing. Modifications induced by fracturation are percussion striae; inner conchoidal scars, some with adhering flakes; anvil striae on the shaft of larger long bones; internal vault releases and concentric fracture cracks on the skulls; crushing of spongy bones; and peeling, predominantly on vertebrae, ribs, scapulae and coxal bones. As for the shaft of the larger long bones, the form of the fragments (shaft circumference and length), as well as the fracture outline, angle and edges, prove green bone breakage: fragments with a circumference less than half the shaft's original circumference represent $85.0 \%$ of all fragments, in particular long and narrow fragments (at least half the shaft's original length). Fractures mainly display curved/V-shaped fracture outlines (63.8\%), oblique angles (52.6\%) and smooth edges (64.5\%). All these results are similar to those observed in Fontbrégoua (France), Mancos (Colorado, USA) and Agris (France), and very different from those measured on dry fractured bones (Villa \& Mahieu 1991; White 1992; Boulestin 1999). 
Table 1. Deposit 9: quantification of human remains and frequencies of cutting-related modifications (cutmarks and scrapemarks) per skeletal element.

\begin{tabular}{|c|c|c|c|c|c|c|c|c|c|}
\hline \multirow[b]{2}{*}{ Element } & \multicolumn{3}{|c|}{ MNE } & \multicolumn{3}{|c|}{ MNI } & \multirow{2}{*}{$\begin{array}{c}\mathrm{PR} \\
\mathrm{A}+\mathrm{C}\end{array}$} & \multirow{2}{*}{$\begin{array}{c}\text { Cutmarks } \\
\mathrm{A}+\mathrm{C}\end{array}$} & \multirow{2}{*}{$\begin{array}{c}\text { Scrapemarks } \\
\text { A }+ \text { C }\end{array}$} \\
\hline & Adults & Children & Perinates & Adults & Children & Perinates & & & \\
\hline Cranium & 4 & 2 & 2 & 4 & 2 & 2 & $75.0 \%$ & $6 / 6$ & $4 / 6$ \\
\hline Mandible & 5 & 0 & 1 & 5 & 0 & 1 & $62.5 \%$ & $5 / 5$ & $3 / 5$ \\
\hline Vertebrae & 54 & 2 & 1 & 3 & 2 & 1 & $29.2 \%$ & $5 / 56$ & $0 / 56$ \\
\hline Sacrum & 1 & 0 & 0 & 1 & 0 & 0 & $12.5 \%$ & $0 / 1$ & $0 / 1$ \\
\hline Ribs & 42 & 18 & 6 & 4 & 2 & 1 & $31.3 \%$ & $7 / 60$ & $0 / 60$ \\
\hline Sternum & 0 & 0 & 0 & 0 & 0 & 0 & $0.0 \%$ & $0 / 0$ & $0 / 0$ \\
\hline Scapula & 9 & 2 & 0 & 5 & 1 & 0 & $68.8 \%$ & $7 / 11$ & $3 / 11$ \\
\hline Clavicle & 5 & 0 & 0 & 3 & 0 & 0 & $31.3 \%$ & $1 / 5$ & $0 / 5$ \\
\hline Humerus & 9 & 4 & 0 & 6 & 2 & 0 & $81.3 \%$ & $9 / 13$ & $2 / 13$ \\
\hline Radius & 10 & 4 & 0 & 5 & 2 & 0 & $87.5 \%$ & $5 / 14$ & $3 / 14$ \\
\hline Ulna & 8 & 3 & 1 & 5 & 2 & 1 & $68.8 \%$ & $6 / 11$ & $3 / 11$ \\
\hline Carpal & 6 & 1 & 0 & 2 & 1 & 0 & $5.5 \%$ & $0 / 7$ & $0 / 7$ \\
\hline Metacarpal & 19 & 2 & 0 & 3 & 2 & 0 & $26.3 \%$ & $3 / 21$ & $0 / 21$ \\
\hline $\begin{array}{l}\text { Hand } \\
\text { phalanges }\end{array}$ & 26 & 6 & 0 & 3 & 2 & 0 & $14.3 \%$ & $0 / 32$ & $0 / 32$ \\
\hline Os coxae & 7 & 2 & 0 & 4 & 2 & 0 & $56.3 \%$ & $2 / 9$ & $1 / 9$ \\
\hline Femur & 10 & 5 & 1 & 5 & 2 & 1 & $93.8 \%$ & $6 / 15$ & $4 / 15$ \\
\hline Patella & 3 & 0 & 0 & 3 & 0 & 0 & $18.8 \%$ & $0 / 3$ & $0 / 3$ \\
\hline Tibia & 9 & 2 & 0 & 6 & 1 & 0 & $68.8 \%$ & $4 / 11$ & $3 / 11$ \\
\hline Fibula & 4 & 2 & 1 & 3 & 1 & 1 & $37.5 \%$ & $5 / 6$ & $1 / 6$ \\
\hline Tarsal & 22 & 1 & 0 & 3 & 1 & 0 & $41.1 \%$ & $1 / 23$ & $0 / 23$ \\
\hline Metatarsal & 26 & 0 & 1 & 4 & 0 & 1 & $32.5 \%$ & $3 / 26$ & $0 / 26$ \\
\hline $\begin{array}{l}\text { Foot } \\
\text { phalanges }\end{array}$ & 9 & 0 & 0 & 1 & 0 & 0 & $4.0 \%$ & $0 / 9$ & $0 / 9$ \\
\hline Sesamoid* & 1 & 0 & 0 & 1 & 0 & 0 & $3.1 \%$ & $0 / 1$ & $0 / 1$ \\
\hline Total & 289 & 56 & 14 & 6 & 2 & 2 & $24.6 \%$ & $75 / 345$ & $27 / 345$ \\
\hline
\end{tabular}

MNE, minimum number of elements; MNI, minimum number of individuals per skeletal portion; PR, percentage representation (for adults and children only). For cutmarks and scrapemarks, the first number in each column is the number of elements (MNE) with the modification, the second number is the MNE for adults and children. ${ }^{*}$ Sesamoid of the first metatarsal.

\section{Evidence for cannibalism}

The assessment of cannibalism in a prehistoric context has up to now relied on two different, although non exclusive and complementary types of demonstration: that faunal and human remains were subjected to similar treatment (Villa et al. 1986a \& b) - based on the assumption that faunal remains must have been butchered - and that the human treatments indicate a functional exploitation of the body and its elements consistent with the extraction of nutrition (White 1992; Boulestin 1999).

Bone modifications indicate that the human individuals were first butchered. For this stage, the analogy between the treatment of the bodies and typical butchery techniques is very well illustrated by the systematic destruction of the transverse processes on thoracic vertebrae on the one hand, and of the posterior parts of the ribs (head, neck and tubercle) on 

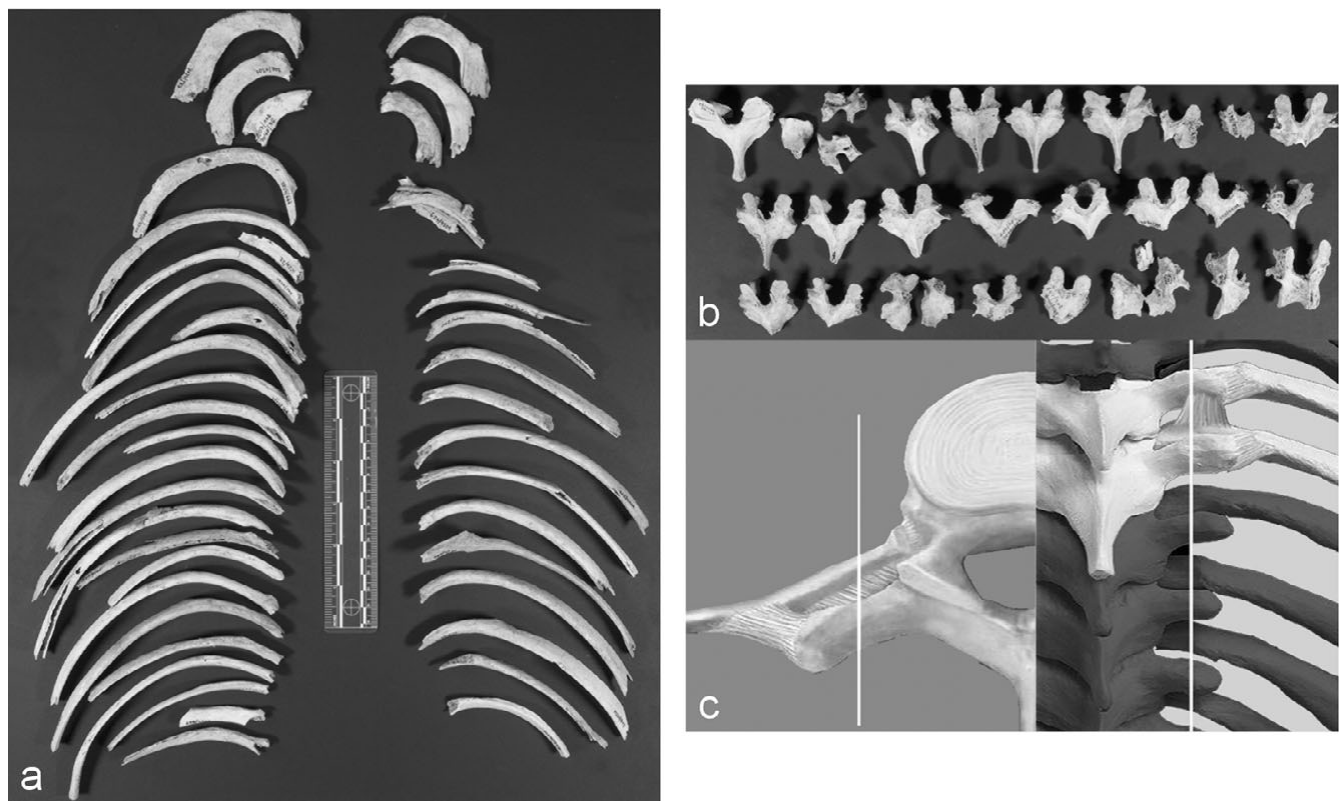

Figure 4. Butchering patterns of the torso: a) destruction of the posterior part of the ribs (head, neck and tubercle) (scale = $150 \mathrm{~mm}$ ); b) systematic destruction of the transverse processes of the thoracic vertebrae and of the vertebral bodies (rich in spongy bone); c) these patterns show that the spines were separated from the carcass according to the method used in butchery (two parallel cuts close to the spinal cord and breaking of the thoracic rib articulations).

the other hand. This pattern is quite similar to the technique used to separate the ribs from the vertebral column observed in animal butchery (Figure 4). After this, heads were skinned following a recurrent pattern: a long incision was made from the root of the nose to the nape of the neck in order to cut the scalp and pull it aside (Figure 3a). Then the temporalis muscles were removed from the cranial vaults and the skulls were broken, perhaps to extract the brain, but carefully so as to preserve the vault. Cut marks and scrape marks on the lingual surface of the mandible show that the tongue was also cut out, while separation of the skull from the mandible caused further marks on the anterior and posterior edges of the ramus. Regarding other parts of the bodies, the long bones of the limbs were intensively defleshed (Table 1) and their marrow cavity exposed, probably by a hammer-on-anvil technique. Processing for marrow is also documented by the presence of scrape marks in the marrow cavity on two fragments. All these observations are similar to those observed in animal butchery.

Nutritionally motivated exploitation of the corpses is also demonstrated by quantitative analysis, and qualitative and quantitative studies of modifications. The distribution of the skeletal parts is very different from that observed in funerary or scavenged assemblages (Haglund 1991). It shows in particular quantitative anomalies that cannot be explained by natural causes (such as differential preservation or loss) and are similar to those observed in Agris or Mancos (White 1992; Boulestin 1999): relative over-representation of the skull, relative under-representation of the rachis (with systematic destruction of the vertebral bodies of the lumbar and thoracic vertebrae, Figure 4), the patella and the iliac part of 
the coxal bones, and lack of sternum (Table 1). All these under-represented elements also contain the highest proportion of spongy bone. There is a clear lack of the extremities of larger long bones, and those containing more spongy tissue have been preferentially destroyed (proximal end of the humerus, proximal and distal ends of the femur and tibia) (Figure 5). The shafts of these long bones also reveal differential breaking: fragments of shaft with a complete circumference represent $38.9 \%$ of the fragments of ulna shaft, $31.6 \%$ of the radius and $29.4 \%$ of the fibula, but only $6.5 \%$ of the fragments of the tibia shaft, $1.8 \%$ of the femur and none of the humerus. The link between the intensity of marrow processing and the volume of the shafts, hence the quantity of marrow they contain, is clearly reflected here (Figure 5). For the carpals and tarsals differential destruction is related to the volume of spongy tissue: the smaller ones are intact whereas the larger ones are usually destroyed. The metatarsals, metacarpals and phalanges reveal a very special breakage pattern: both ends of the first two and the basis of the proximal phalanges of the hands are preferentially broken, whereas the foot phalanges and the middle and distal phalanges of the hands are often intact.

In conclusion, all these observations (anomalies in the distribution of bones and in their different proportions that can be correlated to their relative contents in food resources; human-induced breakage varying according to this content; abundant defleshing; and similarities with animal butchery) allow us to conclude that the individuals from deposit 9 were cannibalised. Moreover, direct proof of this could be provided by the existence of chewing marks. From a morphological point of view, they are perfectly compatible with a human origin, but their characteristics do not allow us to exclude the actions of carnivores, especially dogs (Landt 2004). On the other hand, their distinctive distribution (10 cases out of 16 are situated near the broken ends of metatarsals, metacarpals and phalanges of the hands, and 3 on the olecranon process of the ulna) speaks strongly in favour of human choice rather than more or less random action by carnivores. Finally, it has to be said that even if the causes of death of the individuals could not be determined, it does not mean that they were not killed: several killing techniques leave no marks on the bones, and it is also extremely difficult to distinguish possible bone modifications due to an execution from those related to a post-mortem treatment of the corpses.

\section{Discussion}

Up to now a detailed study has been made only of deposit 9, but the study being done of the other deposits shows the same diagnostic characteristics outlined above. Although further detailed analysis and the definitive count of the human remains for the whole excavated area are as yet lacking, it is highly probable that a great number of the thousand or so individuals probably deposited in Herxheim were subjected to cannibalism.

Cannibalism remains a rare phenomenon during the Neolithic - and prehistory in general - but is probably under-estimated due to the difficulties of recognising and demonstrating it. Today, the only convincing case for the concerned period is Fontbrégoua (Villa et al. 1986a \& b), even if the detailed study of this assemblage remains unpublished. Nevertheless, this practice has been evoked several times, particularly for some German 

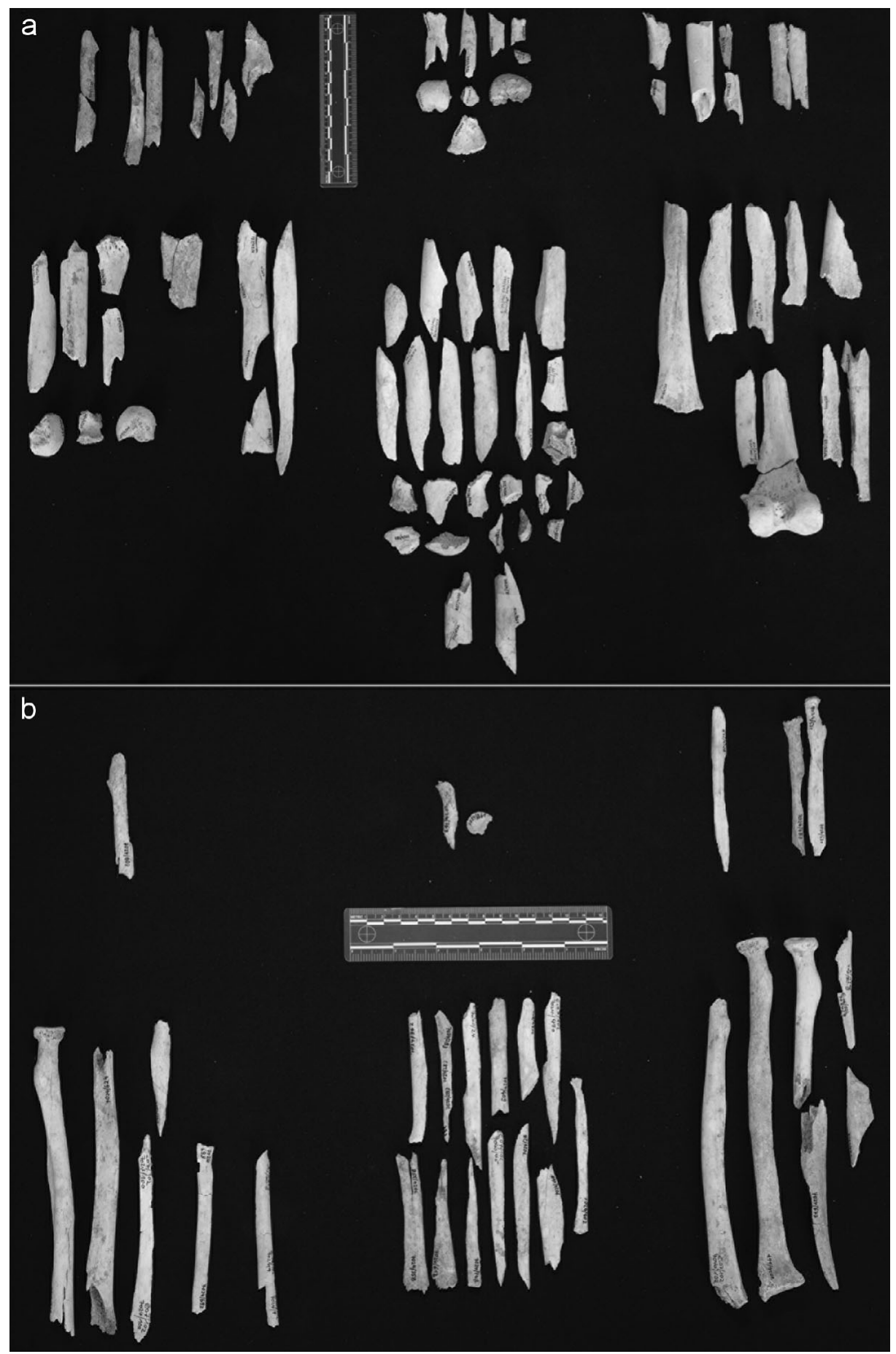

Figure 5. Differential treatment of the long bones: a) diaphyses of the femurs, large and rich in marrow, are systematically broken; b) the radii, not so large and rich in marrow, have a high proportion of unbroken diaphyses. Moreover, most of the more voluminous extremities of the bones, rich in spongy bone, are destroyed. (Scales $=150 \mathrm{~mm})$. 
sites dating from the Linear Pottery Culture: Zauschwitz in Saxony (Coblenz 1962; Grimm 1991), Hanseles Hohl (Zenetti 1924) and Jungfernhöhle (Asmus 1955) in Bavaria, Tillpetersrech (Herrmann \& Jockenhövel 1990) and Ober-Hörgern (Kneipp \& Buttner 1988 ) in Hesse. For most assemblages, the hypothesis of cannibalism has recently been rejected (Orschiedt 1999; Pasda et al. 2004), but considering the results obtained for Herxheim, new exhaustive analyses could be useful.

Cannibalism gave rise to an abundant anthropological literature and to numerous classifications. One of the most common consists in considering accidental or exceptional cannibalism - most often survival cannibalism during famine periods - as opposed to institutional cannibalism, which can be divided into two main categories: endocannibalism, usually funerary, and exocannibalism, mainly related to war. The number of people concerned at Herxheim obviously suggests that cannibalism for the simple purpose of survival is highly improbable, all the more so as the characteristics of the deposits show a standard, repetitive and strongly ritualised practice. Funerary cannibalism is not plausible either: this hypothesis does not seem to be compatible with the number of individuals in relation to the short period during which it took place, and does not take into account the various and sometimes distant origins of the ceramic styles. War cannibalism could be a more attractive hypothesis, but it would force us to consider the possibility of raids sometimes over as far as several hundred kilometres in order to explain the various ceramic styles. Another, very different theory can be put forward: that people came voluntarily to Herxheim, sometimes from very far away, in order to take part in ceremonies in which cannibalism - hence of a sacrificial nature - would have played an important part. It is impossible as yet to decide which hypothesis is more likely, but their assessment will be one of the main objectives of future research. In this context a program of isotopic analysis is being conducted and should provide valuable information concerning the origins of the individuals found in Herxheim.

It is clear, however, that the first conclusions of our study yield a new argument for the theory that a deep crisis shook Central Europe at the end of the Linear Pottery Culture. This crisis sometimes resulted in violent behaviours, which may have been of different kinds: some appear as simple, local or regional armed conflicts, for instance in Asparn or Talheim, whereas others seem to have been more complex, highly ritualised and of greater impact, as evidenced in Herxheim. Hence, this is not only a simple social malfunctioning linked to endemic conflicts phenomena, but a dramatic breaking-off in the traditional behaviours of the Linear Pottery groups. As for the human remains, this breaking-off particularly results in a voluntary destruction of the body integrity of dead people (and, so it seems, also of the goods deposited with them), that is completely in opposition with the traditional practices concerning death. This crisis must be related to the question of how the Linear Pottery period ended. It is certainly not a coincidence if spots of violence happen quite simultaneously in regions far apart, such as the Paris Basin and Lower Austria, and if they are everywhere followed by the collapse in the symbolic system, Linear Pottery groups' actual 'ideological structure'. The existence of slaughters, of possible sacrificial practices, of wars and every other form of social violence fits well with the hypothesis of a millenarist crisis at the end of a cycle. With its given characteristics, Herxeim can be seen as a unique political and/or religious centre for this period, and undoubtedly its study will eventually provide 
fundamental material for our knowledge of the societies in this region at the transitional period between the Early and Middle Neolithic.

\section{Acknowledgements}

From 2004 a multidisciplinary, international team was assembled around a research project financed by the Deutsche Forschungsgemeinschaft (German Research Foundation): Siedlung und Grubenanlage des linearbandkeramischen Fundplatzes Herxheim (Settlement and ditched enclosure of the Linear Pottery Culture site at Herxheim). This team, directed by Andrea Zeeb-Lanz, groups together specialists in physical anthropology, archaeozoology, ceramics, bone and stone tools and botany. We acknowledge our thanks to all the members of the Herxheim research team involved in the recovery and study of the archaeological and anthropological record, and Ludger Schulte for the restoration of artefacts and bones. We thank Jean-Paul Cros for his involvement in the excavation of deposit 9, and Émilie Cartier and Amandine Mauduit for their help in the study of the human remains from this deposit. Our thanks are also due to Emmanuelle Boulestin for the translation of the original French manuscript, and David Wigg-Wolf for revising the English version. We also acknowledge the comments and suggestions made by the reviewers of this article, Daniela Hofmann and Alison Sheridan. The picture 'a' in Figure 3 is by Pascal Disdier (CNRS Strasbourg).

This research was sponsored by the municipality of Herxheim (excavations) and the Deutsche Forschungsgemeinschaft. Additional support is granted to Bruno Boulestin by the Agence Nationale de la Recherche (French State Research Agency) through the project Guerre et violence dans les premières sociétés d'Europe : approche intégrée (War and violence in the first European societies: an integrated approach).

Correspondence and requests for materials should be addressed to Bruno Boulestin (b.boulestin@ anthropologie.u-bordeaux1.fr) or Andrea Zeeb-Lanz (andrea.zeeb-lanz@gdke.rlp.de).

\section{References}

ARKush, E.N. \& M.W. Allen. 2006. The archaeology of warfare. Prehistories of raiding and conquest. Gainesville (FL): University Press of Florida.

Asmus, G. 1955. Die menschlichen Skelettreste aus der Jungfernhöhle, in O. Kunkel (ed.) Die Jungfernhöhle bei Tiefenellern. Eine neolithische Kultstätte auf dem Fränkischen Jura bei Bamberg (Münchner Beiträge zur Vor- und Frühgeschichte 5): 65-77. Munich: C.H. Beck.

Beyneix, A. 2001. Aux origines de la guerre: actes de violence et massacres dans le Néolithique européen. Revue des Etudes Anciennes 103: 329-42.

- 2007. Réflexions sur les débuts de la guerre au Néolithique en Europe occidentale. L'anthropologie 111: 79-95.

BOUlestin, B. 1999. Approche taphonomique des restes humains. Le cas des Mésolithiques de la grotte des Perrats et le problème du cannibalisme en préhistoire récente européenne (British Archaeological Reports International series 776). Oxford: Archaeopress.

Carman, J. \& A. Harding (ed.). 1999. Ancient warfare, archaeological perspectives. Stroud: Sutton.

Christensen, J. 2004. Warfare in the European Neolithic. Acta archaelogica 75: 129-56.

CoblenZ, W. 1962. Bandkeramischer Kannibalismus in Zauschwitz. Ausgrabungen und Funde. Nachrichtenblatt für Vor- und Frühgeschichte 7: 67-9.
FARRUGIA, J.-P. 2002. Une crise majeure de la civilisation du Néolithique danubien des années 5100 avant notre ère. Archeologicke rozhledy 54: 44-98.

GrimM, H. 1991. Menschliche Knochen in bandkeramischen und bronzezeitlichen Gruben von Zauschwitz (Gemeinde Weideroda, Landkreis Borna). Arbeits-und Forschungsberichte zur sächsischen. Bodendenkmalpflege 34: 7-21.

Guilaine, J. \& J. Zammit. 2001. Le Sentier de la guerre. Visages de la violence préhistorique. Paris: Seuil (English translation: The origins of war: violence in prehistory. Malden: Blackwell, 2004).

HaAs, J. (ed.) 1990. The anthropology of war. Cambridge: Cambridge University Press.

HaGLund, W.D. 1991. Applications of taphonomic models to forensic investigations. PhD dissertation, University of Washington. Ann Arbor (MI): University Microfilms.

Herrmann, F.-R. \& A. Jockenhovel (ed.). 1990. Die Vorgeschichte Hessens. Stuttgart: Theiss.

Jeunesse, C. \& P. LeFranc. 1999. Rosheim 'Saint Odile' (Bas-Rhin), un habitat rubané avec fossé d'enceinte. Première partie: les structures et la céramique. Cahiers de l'Association pour la Promotion de la Recherche Archéologique en Alsace 15: 1-111.

KEELEY, L.H. 1996. War before civilization. The myth of the peaceful savage. New York \& Oxford: Oxford University Press. 
KELlY, R.C. 2000. Warless societies and the origin of war. Ann Arbor (MI): University of Michigan Press.

Kneipp, J. \& H. ButTner. 1988. Anthropophagie in der jüngsten Bandkeramik der Wetterau. Germania 66: 489-97.

KRAUSE, R. 1998. Die bandkeramische Siedlung bei Vaihingen. Berichte der Römisch-Germanischen Kommission 79: 5-105.

LANDT, M.J. 2004. Investigations of human gnawing on small mammal bones among contemporary Bofi foragers of the Central African Republic. Unpublished MA dissertation, Washington State University.

LeBlanc, S.A. \& K.E. Register. 2003. Constant battles: the myth of the peaceful, noble Savage. New York: St Martin's Press.

Martin, D.L. \& D.W. FraYer (ed.). 1997. Troubled times: violence and warfare in the past (War and Society 3). Amsterdam: Gordon \& Breach.

OrSCHIEDT, J. 1999. Manipulationen an menschlichen Skelettresten. Taphonomische Prozesse, Sekundärbestattungen oder Kannibalismus? (Urgeschichtliche Materialhefte 13). Tübingen: Mo Vince.

Orschiedt, J. \& M.N. Haidle. 2007. The LBK enclosure at Herxheim: theatre of war or ritual centre? References from osteoarchaeological investigations, in T. Pollard \& I. Banks (ed.) War and sacrifice. Studies in the archaeology of conflict: 153-67. Leiden: Brill.

-2008 . Violence on the living, violence on the dead: the human remains from the LBK site of Herxheim, Germany, in R. Schulting \& L. Fibiger (ed.) Neolithic violence in a European perspective: 16-17. Preprint of the School of Archaeology, University of Oxford conference, 14-15 March 2008. Available at http://www.arch.ox.ac.uk/conferences/ $? \mathrm{a}=2859$ \#Abstract\%20booklet.

Pasda, K., R.-M. Arbogast \& C. Jeunesse. 2004. Menschliche Knochen der linearbandkeramischen Grube Qu 42 von Zauschwitz (ehem. Gmd. Weideroda, Kr. Borna). Cahiers de l'Association pour la Promotion de la Recherche Archéologique en Alsace 20: 121-40.

Pearson, M.P. \& I.J. Thorpe (ed.). 2005. Warfare, violence and slavery in prehistory (British Archaeological Reports International Series 1374). Oxford: Archaeopress.

REYNA, S.P. \& R.E. Downs (ed.). 1994. Studying war. Anthropological perspectives (War and Society 2). Amsterdam: Gordon \& Breach.

Schulting, R. \& L. Fibiger. 2008. Neolithic violence in a European perspective. Preprint of the School of Archaeology, University of Oxford conference, 14-15 March 2008. Available at http://www.arch. ox.ac.uk/conferences/?a=2859\#Abstract $\% 20$ booklet.
Teschler-Nicola, M., F. Gerold, F. Kranz, K. LiNDENBAUER \& M. SPANNAGL. 1997. Anthropologische Spurensicherung. Die traumatischen und postmortalen Veränderungen an den linearbandkeramischen Skelettresten von Asparn/Schletz. Archäologie in Österreich 7: 4-12.

ThORPE, I.J. 2003. Anthropology, archaeology and the origin of warfare. World Archaeology 35: 145-65.

ViLla, P. \& É. MAHIEU. 1991. Breakage patterns of human long bones. Journal of Human Evolution 21: 27-48.

Villa, P., C. Bouville, J. Courtin, D. Helmer, E. Mahieu, P. Shipman, G. Belluomini \& M. BRANCA. 1986a. Cannibalism in the Neolithic. Science 233: 431-7.

- 1986b. Un cas de cannibalisme au Néolithique. Gallia Préhistoire 29: 143-71.

WAHL, J. \& H.-G. KÖNIG. 1987. Anthropologischtraumatologische Untersuchung der menschlichen Skelettreste aus dem bandkeramischen Massengrab bei Talheim, Kreis Heilbronn. Fundberichte aus Baden-Württemberg 12: 65-193.

Wahl, J. \& H.-C. STRIEN (ed.). 2007. Tatort Talheim. 7000 Jahre später: Archäologen und Gerichtsmediziner ermitteln. Heilbronn: Städtische Museen Heilbronn.

White, T. 1992. Prehistoric cannibalism at Mancos 5MTUMR-2346. Princeton (NJ): Princeton University Press.

Wild, E.M., P. Stadler, A. Häusser, W. Kutschera, P. STEIER, M. Teschler-Nicola, J. Wahl \& H.J. WINDL. 2004. Neolithic massacres: local skirmishes or general warfare in Europe? Radiocarbon 46: 337-85.

WindL, H. 1998. Der Brunnen der Linienbandkeramik von Schletz/Asparn a. d. Zaya, p. B. Mistelbach, im Nordosten Österreichs. Materialien zur Bodendenkmalpflege im Rheinland 10: 85-93.

ZeEb-LanZ, A. 2009. Gewaltszenarien oder Sinnkrise? Die Grubenanlage von Herxheim und das Ende der Bandkeramik, in A. Zeeb-Lanz (ed.) Krisen Kulturwandel-Kontinuitäten. Zum Ende der Bandkeramik in Mitteleuropa. Beiträge der internationalen Tagung in Herxheim bei Landau (Pfalz) vom 14-17 Juni 2007. Internationale Archäologie. Arbeitskreis, Tagung, Symposium, Kongress Bd. 10: 87-102. Rahden: Marie Leidorf.

ZeEb-LanZ, A. \& F. HaACK. 2008. 'Positive' violence in Herxheim: the human findings from the Bandkeramik settlement with pit enclosure, in R. Schulting \& L. Fibiger (ed.) Neolithic violence in a European perspective: 25-6. Preprint of the School of Archaeology, University of Oxford conference, 14-15 March 2008. Available at http://www.arch. ox.ac.uk/conferences/?a=2859\#Abstract $\%$ 20booklet. 
ZeEb-LanZ, A. et al. 2007. Außergewöhnliche

Deponierungen der Bandkeramik - die Grubenanlage von Herxheim. Vorstellung einer Auswahl von Komplexen mit menschlichen Skelettresten, Keramik und anderen Artefaktgruppen. Germania 85: 199-274.
ZenetTI, P. 1924. Die Ausgrabungen des Historischen Vereins Dillingen. Die Ausgrabung der Höhle 'Hanseles Hohl' bei Fronhofen im Kesseltal. Jabrbuch des Historischen Vereins Dillingen an der Donau 37: 151-63. 